\title{
Tarsal morphology of the pleuraspidotheriid mammal Hilalia from the middle Eocene of Turkey
}

Gregoire Metais, Ozan Erdal, Korhan Erturaç, and K. Christopher Beard

Acta Palaeontologica Polonica 62 (1), 2017: 173-179 doi:https://doi.org/10.4202/app.00314.2016

Pleuraspidotheriids are a group of primitive ungulate mammals that, until recently, were thought to be restricted to the late Paleocene of Western Europe. It has been hypothesized that this family actually survived in Central Anatolia until at least the middle Eocene. However, these anachronistically young Anatolian "survivors", including the genus Hilalia, were previously documented mainly by dental remains. Here, we describe the previously unknown astragalus of Hilalia saribeya, which confirms the pleuraspidotheriid affinities of the genus, and supports phylogenetic reconstructions that place Hilalia as the sister group of Pleuraspidotherium. The morphology of the astragalus suggests sub-cursorial plantigrade locomotion for H. saribeya, although its tarsal morphology remains generalized enough that scansorial capabilities cannot be ruled out. The evolution of Hilalia is addressed in the context of the apparent geographic isolation of Central Anatolia during the Eocene. The endemic character of the mammalian fauna of Central Anatolia during the middle Eocene emphasizes how the complex paleogeography of the northern margin of Neotethys impacted local biotas in a region situated at the crossroads of very distinctive biogeographic zones.

Key words: Mammalia, Pleuraspidotheriidae, paleogeography, Eocene, Turkey, Anatolia.

Grégoire Métais [metais@mnhn.fr], CR2P, Paléobiodiversité et Paléoenvironnements, UMR 7207 (CNRS, MNHN, UPMC), Sorbonne Université, Muséum National d'Histoire Naturelle, 8 rue Buffon, 75005 Paris, France; and Department of Ecology \& Evolutionary Biology, University of Kansas, Lawrence, Kansas 66045, USA. Ozan Erdal [erdalo@itu.edu.tr], Eurasia Institute of Earth Sciences, İstanbul Technical University, Istanbul, Turkey. Korhan Erturaç [erturac@gmail.com], Department of Geography, Sakarya University, 54187 Esentepe, Sakarya, Turkey. K. Christopher Beard [chris.beard@ku.edu], Biodiversity Institute, University of Kansas, Lawrence, Kansas 66045, USA; and Department of Ecology \& Evolutionary Biology, University of Kansas, Lawrence, Kansas 66045, USA. 
This is an open-access article distributed under the terms of the Creative Commons

Attribution License (for details please see creativecommons.org), which permits unrestricted use, distribution, and reproduction in any medium, provided the original author and source are credited.

Forif Full text $(1,547.9 \mathrm{kB})$ 